\title{
Context in Distinguishing between Overt and Actual Functions of Polite Speech Acts
}

\author{
Mojde Yaqubi (Corresponding Author) \\ School of Translation and Interpretation, University of Ottawa, Ottawa \\ 70 Laurier, Ottawa, Canada \\ E-mail: myagubi@uottawa.ca \\ Wan Rose Eliza Abdul Rahman \\ Translation \& Interpreting Section, Universiti Sains Malaysia \\ 11800 Pulau Pinang, Malaysia
}

Asieh Hadavandkhani

Faculty of Foreign Languages, Islamic Azad University, Central Tehran Branch

Shahrak-e Qods st, Tehran, Iran

Received: September 12, 2019 Accepted: September 24, 2019 Published: September 25, 2019

doi:10.5296/jsel.v7i1.15522 URL: https://doi.org/10.5296/jsel.v7i1.15522

\begin{abstract}
Previous mono-cultural and interlanguage pragmatic studies in Persian mainly focused on the 'strategy types' used in the structures of speech acts. However, the functions of these elements were discussed by few of them. Polite speech acts have been reported to be used with both genuine and ostensible meanings. Nevertheless, few sporadic studies were conducted to help distinguishing these two series of speech acts in Persian. In this study, attempt is made to highlight the importance of context in distinguishing between overt (direct) and actual (indirect) functions of four speech acts namely offer, invitation, apology and refusal collected from the soundtracks of Iranian films. In this study we propose that while the overt and actual functions of the genuine speech acts are the same, there is discrepancy in the case of ostensible speech acts. The results of this study highlight the importance of context in working out the meaning of Persian speech acts.
\end{abstract}

Keywords: Pragmatics, context, speech act, function, Iranian film, Persian 


\title{
1. Background
}

\subsection{Pragmatics and Context}

From centuries ago, the contrast between 'what is said' versus 'what is meant' has held a fascination for scholars in different disciplines such as pragmatics which show no signs of diminishing. The term 'pragmatics' was primarily applied by American philosopher Charles Morris (1938) who distinguished among three distinct branches of semiotics (science of signs), namely 'syntax', the study of "the formal relation of sign to one another", 'semantics', the study of "the relations of signs to the objects to which the signs are applicable" and 'pragmatics', the study of "the relation of signs to interpreters" (p. 6). Compared to syntax and semantics, pragmatics is a young science put in this triad of studies which was discouraged by many scholars in the first years of its emergence. Ariel (2010, p. 23) describes the delimitation of pragmatics in 1970s and 1980s and argues "as a newcomer to the linguistics scene, pragmatics was in need of a conceptual positive definition in order to become respectable discipline". Leech (1983) describes pragmatics in those years of ignorance as 'rag-bag' in which recalcitrant data could be conventionally stuffed. For philosophers and logicians, pragmatics was reported to be called as wastebasket of linguistics (Yule, 1996; Ariel, 2010) or 'Cinderella' of the three studies of semiotics (Capone \& Mey, 2015). Nevertheless pragmatics was developed and its importance became increasingly clear to applied linguistics owing to the fact that there were many issues in studying languages which could not be answered by semantics and syntax. As Leech (1983) argues "we cannot really understand the nature of language itself unless we understand pragmatics (p. 1). The distinction between semantics and pragmatics in explaining the meaning has been focus of many studies. Leech \& Thomas (1990, p. 101) maintain that:

\begin{abstract}
"semantics has to do with meaning as a dyadic relationship between a form and its meaning: $\mathrm{x}$ means y (e.g. "I am feeling somewhat esurient" means 'I am rather hungry'). Whereas pragmatics has to do with meaning as a triad correlation between $S$, meaning and form/utterance: $S$ means y by x (e.g. $S$ is uttering the words "I am rather hungry" is "requesting something to eat).
\end{abstract}

Context is an important notion in distinguishing semantics and pragmatics in the literature. It is a complex notion which has been defined differently in various disciplines. Black \& Bunt (2000, p. 4) believe that there are four types of contexts related to the field of pragmatics. These types are: 1) discourse context which refers to the objects that have been introduced in the preceding discourse, 2) physical and perceptual context which refers to objects that are known to be present or visible (or audible) in the speaker and hearer's environment' events and actions perceivable in that environment, 3) spatiotemporal information which refers to the time and place of speaking and 4)attitudinal context which refers to what a speaker/ hearer believes, intends, knows, fears. Fasold (1990, p. 119) regards the science of pragmatics as the study of the use of context to make inferences about meaning. Some scholars used specific terms such as the study of literal, conventional or context-independent meaning 
versus non-literal, non-conventional or context-dependent meaning (Cole, 1981; Lyons, 1987; Black \& Bunt, 2000; Kadmon, 2001; Recanati, 2004) to distinguish semantics and pragmatics and also to highlight the importance of pragmatics in terms of its context-independency in interpretation of meaning. Roberts (2004, p. 197) argues that "we complain if someone quotes what we say out of context because this may distort our intended meaning".

\subsection{Genuine Speech Acts Studies}

In his posthumous seminal book How to Do Thing with Words, Austin (1962) distinguished between two kinds of utterances called 'constatives' and 'performatives' with dual functions of 'stating' (conveying information) and 'doing actions' respectively. He postulated that in contrast to constatives which are straightforward statement of fact (such as "the sky is blue"), performatives are not applied to state something or to make true or false statements but they are produced by people to 'perform' an action. e.g. by using the performative "I resign", the speaker (S) really does the act of reassigning. He distinguished between explicit and implicit performatives. While in the former, the utterance contains the verb such as 'I hereby promise that I shall be there', in the latter the meaning of the performative will be deciphered implicitly such as 'I shall be there'.

The study of performatives led to the hypothesis of 'speech act theory'. In place of the initial distinction between constatives and performatives, Austin claims that the speech act can embody three types of acts namely locutionary act (locution), illocutionary act (illocution) and perlocutionary act. Austin and his followers concentrated on 'illocutionary act' more than the other two acts. Sadock (2007, p. 54) calls illocutionary act as "acts done on speaking" and differentiates them with "acts of speaking" and "acts performed by speaking" which refer to locutionary acts and perlocutionary acts respectively. Salmani Nodoushan (2014, p. 4) argues that illocutions occupy the middle ground between locutions and perlocutions, and this middle ground has come to be known as the territory of pragmatics - or of meaning in context.

Similar to the other pragmatic aspect of utterances, context plays an important role in interpretation of the meaning of speech acts. With reference to this importance, Jucker \& Taavitsainen (2008, p. 5) argue that:

Meaning-making processes are sensitive to context and the meaning of an utterance maybe completely different in different contexts, for example, the sentence "your hair is so long?" could be an expression of several speech acts with different meanings, depending on the contexts. It could be an indirect command "have your hair cut", an insult or a compliment or just a neutral statement.

Searle crystallized the concept of 'speech acts' once more and categorized them into five basic kinds in her taxonomy based on a number of pragmatic parameters some of which are closely related to the felicity condition (Sadock, 2007, p. 65). These categories are declaratives, representatives (assertive), expressives, directives and commisives. The following table shows the classifications of speech acts cited by Yule (1996, p. 53): 
Table 1. Categories of Speech Acts

\begin{tabular}{|l|l|}
\hline $\begin{array}{l}\text { Name of the } \\
\text { Category }\end{array}$ & \multicolumn{1}{c|}{ Definition } \\
\hline Declaratives & Those kinds of speech acts that change the world via their utterance. \\
\hline $\begin{array}{l}\text { Representatives } \\
\text { (assertives) }\end{array}$ & $\begin{array}{l}\text { Those kinds of speech acts such as concluding, asserting, boasting, } \\
\text { complaining, and stating, by using which S states what s/he believe } \\
\text { or to be the case or not. }\end{array}$ \\
\hline Expressives: & $\begin{array}{l}\text { By using these kinds of speech acts, S expresses psychological states } \\
\text { such as pleasure, pain, likes, dislikes, joy, or sorrow }\end{array}$ \\
\hline Directives & $\begin{array}{l}\text { Those kinds of speech acts such as invitation, request, asking, } \\
\text { recommending and ordering that S use to get someone else to do } \\
\text { something. They express what S wants. }\end{array}$ \\
\hline Commisives & $\begin{array}{l}\text { Those kinds of speech acts such as promise and refusals that S uses to } \\
\text { commit themselves to some future action. }\end{array}$ \\
\hline
\end{tabular}

Since speech act has been postulated by Austin (1962) several studies attempted to confirm universality or culture-specificity of speech acts. Cross-Cultural Speech Act Realization Patterns (CCSARP) project is one of the movements in investigating the similarities and differences of speech acts such as request, refusal and apology among different languages and cultures. These studies mainly concentrated on identification and comparison of the 'strategies' (locutions, forms or structures) which are utilized in performing specific speech acts.

During the past decade, there has been an unprecedented growth in Persian mono-cultural, interlanguage and cross-cultural studies on pragmatic issues relevant to speech acts such as implicature (Yaqubi, et al. 2016), face-threatening acts and politeness (Yaqubi, 2012, Yaqubi et al., 2013). A thorough review of all Persian pragmatics falls beyond the scope of this study, as the main aim here is to investigate the overt versus actual functions of Persian genuine and ostensible speech acts. Therefore, the relevant previous studies on Persian speech acts and language function will be outline in the next sections.

\subsection{Persian Speech Act Studies}

In an attempt to understand the intricacies of meaning in Persian, one can rely on the knowledge of this language from different points of view such as pragmatics. Elaborating on the distinction between semantics and pragmatics, Beeman (1986) argues that "The Iranian linguistic situation presents a genuine challenge to this doctrine of separation" (p. 2). He refers to shortcoming of semantics in explaining the meanings of words in Persian. He writes:

Early in my research I came to the conclusion that in order to understand the nature of language and communication in Iran, I would have to stop addressing myself to problems like, "What is the full range of referents for X?" or "What are the selective restrictions on the use of the verb Y?" in some culturally neutral (hence artificial) analytic framework. Instead, I would have to address 
myself to a set of far more basic and salient questions, such as, "how are Iranians using their language to make themselves understood? How are Iranians establishing the criteria for interpretation of their language in interaction with others? (p. 3).

During the past decade, there has been an unprecedented growth in cross-cultural/ linguistic, interlanguage and mono-cultural studies on genuine speech acts in Persian (Afghari, 2007; Allami, 2012; Aliakbari \& Changizi, 2012) in which researchers tested the universality of strategies used in speech act proposed by global studies. Despite of the fact that these studies had contributed to the field of pragmatics in Persian language, they only focused on the linguistic forms and structure of these speech acts while their functions in different contexts have been ignored by these studies.

In some interdisciplinary studies ((Taleghani-Nikazm, 1998; Koutelaki, 2002; Yaqubi, 2018; Yaqubi, forthcoming(a)), researchers borrowed cultural and social concepts from different disciplines such as cultural linguistics and anthropology to define a series of speech acts which are extended to abide by the norms of ritual politeness, which is glossed as ta'a arof in Persian. Ta'ârof entails variant cultural routine formalities, behaviours or acts such as using nice and soft words, persistent offering, inviting, refusing and apologizing, long greeting and exaggerated praising. Amouzade (2001, p. 9) maintains that ta'ärof constitutes the abstract basis of polite interactions. Koutlaki (1997) (as cited by Sahragard, 2003, p. 399) argues that any description or analysis of the Iranian politeness system without a reference to this concept will be deficient and incomplete. Speech acts used in doing ta'ärof have been reported to be used with both positive (i.e. sincere, real or genuine) and negative (insincere, unreal, fake or ostensible) meanings.

The issue of universality vs. cultural specificity of Persian speech acts had motivated a great number of studies on genuine speech acts. However, in the relatively limited literature on ta'ārof from pragmatics point of view, there are few researchers who carried out studies on the meanings of speech acts used in doing ta'ärof. Analysis of the examples of speech acts set by researchers reveals that interlocutors involved in $t a$ 'ärof do not always mean by what they say in extending ritual speech acts which makes the interpretation of the meaning of ta' $\bar{a}$ rof difficult both among the native and non-native speakers of Persian.

In the past few years, the concept of ostensible speech acts (OSAs) from the study by Isaacs \& Clark (1990) has been adopted in sporadic studies (Eslami, 2005, Salmani Nodoushan, 2005, Koutlaki, 2010, Babai Shishavan \& Sharifian, 2013; Babai Shishavan, 2016; Yaqubi, forthcoming(b)) to define the negative aspect of $t a$ 'ârof, as well as to help distinguish a series speech acts such as invitation, offer, refusal of offer and invitation and apology from their genuine counterparts. Persian OSAs are used as a tool to fulfil the requirements of ta'arof i.e. hospitality, cordiality, respect, politeness, saving or enhancing the faces of the $\mathrm{S}$ and $\mathrm{H}$ as well as modesty or humility.

Intercultural and monocultural pragmatic studies on Persian OSAs indicate that in contrast to English OSAs by using which $\mathrm{S}$ implies his/her meaning by linguistic features, in making or 
doing ta'ärof, interlocutors signal ostensible meanings of these speech acts such as hedge and vague language, in Persian specific contexts including particular times, place and people signal ostensible meaning and help $\mathrm{H}$ to distinguish genuine from ostensible speech acts.

\subsection{Language Functions}

Nord (1988/2006) adopted Buhler's Organon model (1934) which included the triad of functions namely informative, emotive and conative, and added phatic function to complete his model. The set of functions proposed by Nord (2006) and the categories of speech acts (cf. table 1) which have these functions (Ephratt, 2008) are as the following:

Referential (informative) function: It refers to the plain communication of information, knowledge, etc. Declaratives and assertives have referential function.

Expressive (emotive) Function: It refers to the attitudes of the speaker towards the object. Expressives such as thanks, apology, congratulation, compliment, blame, condole has expressive function.

Appellative (conative) Function: having the reader (listener) in focus, this function has the intention of inducing the receivers to do something. Commisives such as offer, promise, refusal s and also directive such as invitation, request, etc. have appellative function.

Phatic Function: This function aims at opening and closing the channel between the sender and the receiver, and to make sure it remains open as long as the sender and receiver want to communicate (p. 135).

As cited by Hebert (2011), Arcand and Bourbeau (1995) distinguished between two types of functions namely 'actual' versus 'overt' or 'direct' versus 'indirect' functions. Hebert (2011) set two examples from their work in order to distinguish these two types of functions. Citing from Arcand and Bourbeau (1995, p. 30-33) he argued that appellative (conative) function is manifested directly in "Go answer the door" and indirectly in "The doorbell rang" (which is equivalent to "Go answer the door"). In other words while the overt and actual functions of the former are the same, in the latter, there is a discrepancy between these two functions (the structure signal referential function while it has appellative meaning).

\section{Method}

For the data collection, examples of four categories speech acts namely refusal, invitation, offer and apology with both genuine and ostensible meaning were collected from the corpus of 15 Iranian films. The rationale behind this selection is their relevancy to the mechanism of ta'ärof. To this aim, the strategies used in the structures of speech acts were identified based on previous studies (Afghari, 2007; Allami, 2012; Aliakbari \& Changizi, 2012; Yaqubi et al, 2016; Yaqubi, forthcoming (a)).

Unlike previous studies which in line with Searle (1969) includes offer in the category of commissive (cf. table 1), in this study, this speech act was included in the category of directives. Eslami (2005, p. 454) argues that: 
Inviting, as an illocutionary act, like offering, is a commissive act, whose point is "to commit the speaker to some future course of action" (Searle1979: 14). In issuing an invitation, the speaker $(\mathrm{S})$ makes a commitment to provide a course of action that is beneficial to the hearer $(\mathrm{H})$. At the same time, invitations are directive in that they instruct the $\mathrm{H}$ to do something, that is, to take up the invitation. In this sense, an invitation is also a directive-an attempt "by the speaker to get the hearer to do something" (Searle 1979: 13).

Eslami (2005) and other scholars' arguments on the similarity of invitation and offer speech acts justify the adoption of offer strategies to identify invitation strategies in Persian. This framework has been used to realize Persian offers and invitation in Persian by Yaqubi et al. (2016).

In this study the concept of context covers all four types of contexts (Black \& Bunt, 2003) (cf. section 1.2). In this paper, attempt was made to analyze the importance of context in distinguishing overt versus actual function of genuine and ostensible speech acts. To this aim, contextual features such as people, time and places which distinguish genuine and ostensible speech acts were adopted from the previous studies (Koutlaki, 2002; Eslami, 2005; Leone, 2009; Babai Shishavan, 2016; Yaqubi, 2018; Yaqubi, forthcoming (b)).

Yaqubi et al. (2014) argue "this (ta'ārof) cultural phenomenon is considered as one of the most prevalent activities and behaviours of Iranians which is done with performing a series of speech acts whose function is phatic (p. 95). In line with Yaqubi et al (2014, 2015), we proposed that the function of Persian OSAs is phatic. However, it is important to mention that OSAs are only a part of ta'ārof and they do not cover the whole ranges of meanings and functions of this phenomenon.

\section{Data Analysis}

Based on the framework, 312 speech acts were distinguished from their genuine counterparts in the corpus. They include 189 genuine and 123 ostensible speech acts. In the following examples of both genuine and ostensible speech acts along with their overt and actual function are analyzed.

Invitation: Eslami differentiated between English and Persian OSA by listing a set of contexts and functions in which Persian ostensible invitation happen. These contexts and functions which constitutes the features of Persian ostensible invitation and are prior to the features proposed by Isaacs \& Clark (1990) include a) to start a conversation, b) to end phone conversations (preclosing/ closing), c) to end face to face planned or unplanned conversations (closing), d) to exchange topic, e) to cancel a half-arranged invitation, f) to invite unexpected visitors out of courtesy and g) to show politeness to someone passing by your house (p. 479). Invitations in the corpus were used with both genuine and ostensible meaning. In the following conversation taken from the movie Under City's skin (2001), an example of ostensible invitation is set: 
[1]

Context: The conversation occurs between a customer who has gone to a restaurant with her family for dinner, and the restaurant owner. They fairly know each other.

\begin{tabular}{|c|c|}
\hline \multirow[t]{3}{*}{ Customer } & $\begin{array}{l}\text { Salam Homayoun xan } \\
\text { [hi] [homayoun] [Mr.] } \\
\text { Hi Mr. Homayoun }\end{array}$ \\
\hline & $\begin{array}{l}\text { Hal-et } \\
\text { [your mood] } \\
\text { [is good][father]? } \\
\text { How are you? }\end{array}$ \\
\hline & $\begin{array}{l}\text { Befarmā-id } \\
\text { [command] } \\
\text { Please sit }\end{array}$ \\
\hline
\end{tabular}

$\begin{array}{llr}\text { Restaurant } & \text { Salam } & \text { xānum } \\ \text { owner } & {[\text { hi] }} & \text { [Ms.] } \\ & \text { Hi Madame }\end{array}$

Hal-e-tun xub-e?

[mood of you][ good is]?

How are you?

Xosh āmad-id

[welcome]

Welcome

Customer Salam dast-e-tun dard na-kon-e

[hi] [hand of you] [pain] [it may not have]

Thank you so much

Hāl-e shomā xub-e?

[Mood of] [you [good is]?

How are you?

\section{Tashrif na-yāvord-in mānzel-e mā}

[presence][you did not bring][house of] [we]

You have not come to our house yet

Qarārbud ye shab biā-in kufte barā-tun doros kon-am [supposed][one][night][ come you-PL][meatball] [for you] [I make]

You supposed to come sometime to try my meatballs for dinner 


$\begin{array}{llll}\text { Restaurant } & \text { Chashm } & \text { zahmat-e-tun } & \text { mid-am, befarmā-in } \\ \text { owner } & \text { [ok] } \quad \text { [bother of you] } & \text { [I give], [command you-PL] } \\ & \text { Sure, I will come, please sit }\end{array}$

In this example, the customer is extending an ostensible invitation to have phatic communication i.e. 'exchange topic'. The context, i.e. place of the invitation indicates that the customer does not intend her invitation to be taken as serious by the restaurant owner. In fact, there is a discrepancy between overt and actual functions of this speech act. In other words, while the overt function of the invitation is appellative, the actual function is phatic. In the following extract taken from Episode 1 of TV series (Life is a Gift) (2009) (Life is a Gift) (2009) (minutes 12:52-58) an example of genuine invitation is given:

[2]

Context: The conversation occurs between an old man who has come from another city and who is waiting at his nephew's house and one of the neighbors of his nephew

\begin{tabular}{|c|c|}
\hline $\begin{array}{l}\text { The } \\
\text { neighbor }\end{array}$ & $\begin{array}{l}\text { Khob } \\
\text { [well] } \\
\text { All right }\end{array}$ \\
\hline & $\begin{array}{l}\text {-Bardār vasāyeleto } \\
\text { [take] [your stuffs] } \\
\text { Take your stuffs }\end{array}$ \\
\hline & $\begin{array}{l}t \bar{a} \quad b \bar{a} \quad h a r \\
\text { [so that [with][each other] [v } \\
\text { Let's go to my place }\end{array}$ \\
\hline $\begin{array}{l}\text { The old } \\
\text { man }\end{array}$ & $\begin{array}{l}\text { Zahmat-e-t mish-e } \\
\text { [trouble of you][it will be] } \\
\text { I will trouble you }\end{array}$ \\
\hline $\begin{array}{l}\text { The } \\
\text { Neighbour }\end{array}$ & $\begin{array}{l}\text { Bardār dige } \\
\text { [take] [any more] } \\
\text { Come on! }\end{array}$ \\
\hline
\end{tabular}

In this example, the context in which this invitation is used (the invited person is an old man who does not have anywhere to go and the neighbour knows about it) signals genuine meaning of the invitation. This context has not been included in the series of contexts which Eslami (2005) defined for Persian ostensible invitations. His insistence in the second 


\section{Macrothink

invitation with the increasing level of persisting shows that he is using non-phatic (genuine) invitation (he is serious in his invitation). Despite the old man's refusal, the neighbour insists on his invitation which leads to the old man's acceptance. Therefore, it can be concluded that the overt and actual functions of this speech act are the same (appellative).

Offer: Analysis of data revealed that Persian offers are used with both genuine and ostensible meaning. Koutlaki regards offer as the main meaning of ta'arrof and argues that the meaning of ta'arof as offer figured prominently in the interviews with (Persian) native speakers (p. 1741). In the literature, offers extended in making ta'ārof has been identified in different contexts and functions such as compliment response strategy, (Leone, 2005; Razmjoo et al., 2013; Yaqubi, forthcoming (a)). These offers are extended with ostensible rather than genuine meaning as by extending them $\mathrm{S}$ does not mean by what he or she says and normally it is not taken as serious by $\mathrm{H}$ and is subsequently refused. Similar to invitations, ostensible offers can be distinguished from their genuine counterparts by the situation they are used and the people involved. The ostensible meaning of these offers can be inferable by the amount of the persistence or insistence. Therefore, similar to English ostensible invitations, upon making an ostensible Persian offers, the speaker does not persist or insist on the offer. Koutlaki (2010, p. 46) argues that:

If you want your offer to be accepted, you need to insist for much longer than you are used to, at least twice or three times, reassuring the person that you can spare it, it's no inconvenience, and you want them to have it.

[3]

Context: In this conversation a group of poor workers (Worker 1, 2 and 3) who are living together in a small house are offering their rich guest Ardeshir who is in his 50s.

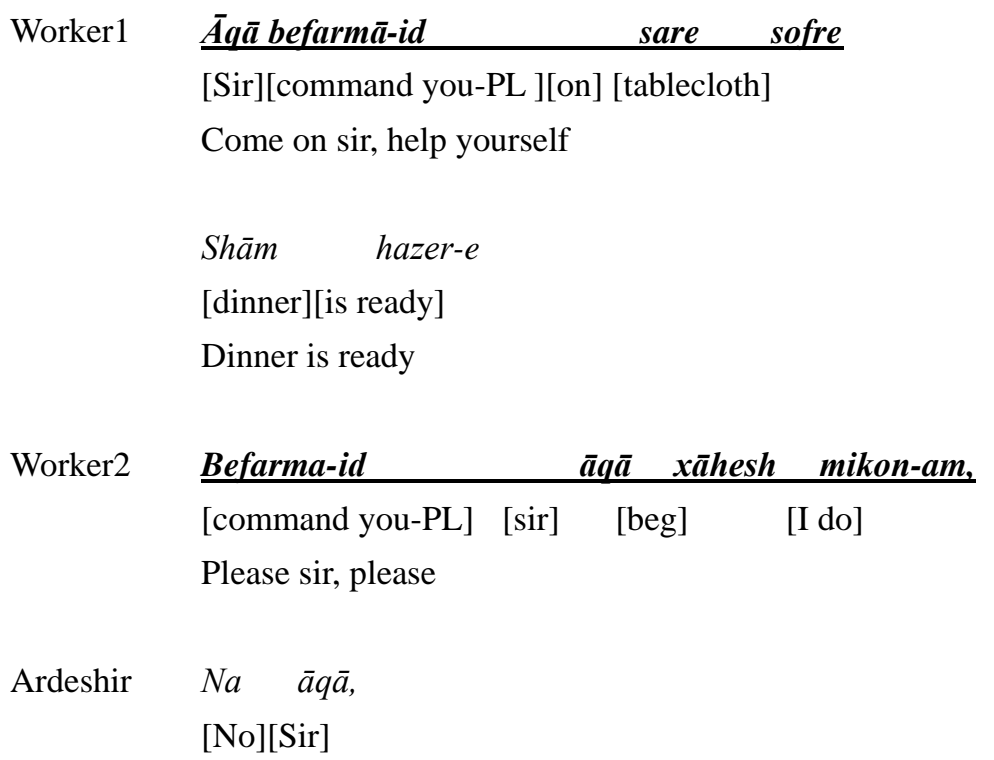


thanks sir

Man eshtehā nadār-am

[I] [appetite] [I do not have]

I am not hungry

Mozāhem-e shomā ham ne-mish-am

[disturber of] [you-PL][also][I will not be]

I do not disturb you

$\begin{array}{lc}\text { shomā qazā-tuno } & \text { befarmā-id } \\ \text { [you][your food] } & \text { [take you-PL] }\end{array}$

Help yourselves

Worker2 āqā ta'ārof mikon-i?

[sir] [ta'ārof] [you do?]

Are you being polite sir?

Worker2

ye omlet-am $\quad$ ba mā boxor dige,

[one][omelet also][with] [we] [eat] [anymore]

Try omlet with us

\section{Worker2 Befarmā-in}

[command you-PL]

Please

Worker1 albate be daspoxt-e manzel ne-mires-e

[of course][to][cooking of][house] [it does not reach]

Vali befarmā-in

[but][you command you-PL]

Of course it is not as good as what you eat at home but please help yourself

Ardeshir $\quad \bar{a} q \bar{a}$ xāhesh mikon-am, befaqrmā-in shomā

[sir][request] [I do] [you command][you]

Please do not say that, please help yourselves

In this example taken from episode 32 of the Iranian series Lodgers (2010) (minutes: 6:30-7:13), the hosts are offering the food to the guest genuinely. Both Ardeshir (guest) and original audience know that hosts are expected to offer the foods frequently to fulfil the requirements of ta'ārof i.e. to show dast-o delbāzi or generosity and mehmān navāzi or hospitality. Normally Iranians show their hospitality through insistent offering of foods and refreshments. According to Koutlaki (2010, p. 44) "ta' ârof is a "polite communication style 


\section{Macrothink}

that its practice stems from religious teachings of generosity and hospitality". Sahragard argues that it may involve using flowery language, expressing strong and repetitive insistence that the guest eat something, degrading the host's belongings and capabilities, etc. (p. 417). Based on the analysis of the data, except in rare situations, hosts offer food and refreshments genuinely. Similarly, in this case, the context i.e. the people (between host and guest), place (the host's house) and time (serving refreshments) imply this meaning. Due to the genuine meaning, both overt and actual functions of this offer are appellative. In the following example taken from the Tele-film Birds of a feather (2011)(minutes 32:06-32:10), the shopkeeper extends an ostensible offer:

[4]

Context: The conversation is between a man who works in a photocopy shop and a customer. The man has copied some pages for the customer

$\begin{array}{ll}\text { Shopkeeper } & \text { Bash-e age nist } \\ & {[\text { Leave it] [if][there is not] }} \\ & \text { You can keep that }\end{array}$

In this conversation, both the customer and the audiences know that offers of money by the shopkeepers are ostensible. In other words, despite frequent offer of money, no customer can leave without paying the money. Koutlaki (2002, p. 1753) maintains that this practice is to ensure that the customer will shop there again, even if the prices are slightly higher than elsewhere. This fact is true about the people who have relative or close relationships. Therefore, the context helps the customer to interpret the meaning of offer and pay at the end of conversation. While the overt function of the offer is appellative, its actual function is phatic.

Apology: Analysis of the data showed that while all the offers of food by the host are genuine in the corpus, by contrast, all apologies extended by the host were ostensible in the context. These apologies were used when no insult has been committed by the host which signal genuine meaning (Shariati \& Chamani, 2010). Normally these apologies are used for bad food or hospitality. Similar to the other OSAs, overt and actual function of these speech acts are not the same. In other words, while the overt function is expressive, their actual function is phatic. Here is an example of these apologies taken from the tele-film The Crystals of Rain) (2010) (minutes 23:16-23:30):

[5]

Context: the conversation occurs between a host and guest

$\begin{array}{ll}\text { Host } & \text { Befarma-id } \\ & \text { [command you] } \\ & \text { Here you are }\end{array}$




\author{
Xeili mamnun \\ [very much][indebted] \\ Thank you \\ Bebaxsh-id \\ [forgive] \\ Sorry \\ dam kardan-e chay tul keshid \\ [brewing of] [tea] [long ][took] \\ It took me a little long to make the tea
}

Refusal: The results of studies on ostensible or $t a^{\prime}$ arrof refusal which are extended in reply to the invitation and offer (Taleghani Nikazm, 1998; Koutlaki, 2002; Salmani-Nodoushan, 2005; Eslami, 2005; Babai Shishavani \& Sharifian, 2013; Miller, et al., 2014; Babai Shishavan, 2016) show that in formal social contexts, Iranians are expected to refuse (reject) offers and invitations once or more times with uttering different reasons before accepting them, while in the same settings, the same refusals are absent or less frequently applied by English speakers. Normally Iranians use different expressions in these settings such as "barāye shoma zahmat mishe" (it'll cause you trouble), which as (Koutlaki, 2010) argues it conveys the speaker's desire to accept. Eslami (2005) analyzed the genuine and ostensible refusals of these invitations in Persian. By observing the examples of invitation-refusal pair, she maintains that if the reason for refusal was the inability of B (addressee) to attend the event, the insistence and repetition of invitation seemed to be less. However, when the reason was not to impose on the inviter, then it would become clear that the refusal was ta' $\bar{a} r o f$ (ostensible refusal) and the inviter continue insisting until the invitation was accepted (p. 466).

Based on the corpus, refusals proved to be used with both genuine and ostensible meanings. Here is an example of genuine refusal taken from the tele-film From the alleys of rain)(2009) (23:16-23:21):

[6]

Context: The conversation happens between an old man in his 60s who wants to help his friend who is younger than him to carry his loads.

$\begin{array}{llr}\text { Old man } & \begin{array}{l}\text { Bede man komak-et } \\ \text { [give][me] }\end{array} & \text { konam } \\ & \begin{array}{l}\text { Let me help you } \\ \text { YI do] }\end{array} \\ \text { Young } & \text { zahmat nakesh zahmat nakesh } \\ \text { man } & \text { [don't bother] [don't bother] } \\ & \text { Do not bother yourself }\end{array}$

In this example, the old man ostensibly offers to help the young man. However, the young man refuses the offer genuinely. Context i.e. the age of the character help the audience to 


\section{Macrothink}

Journal for the Study of English Linguistics

ISSN 2329-7034 2019, Vol. 7, No. 1

interpret the meaning of the offer. The final action (young man's carrying the stuffs) shows that the young man has worked out the meaning of the offer. In this example the overt and actual functions of the refusal is appellative. In the following an example of ostensible refusal taken from episode 1 of the tele-film Life is a Gift (2009) (minutes 9:53-10:39):

[7]

Context: The conversation occurs between an old man who has come from another city and who is waiting at his nephew's house and one of the neighbors of his nephew

Neighbour Mig-amā biā ber-im xune-ye mā,hā?

[I say] [come][let' go][house of] [we][ok?]

Look, let's go to my place

Ber-im

[lets go]

Let's go

-har az gāhinane Badri mādar-am miād

[any][from][time][nany][Badri][my mom][comes]

Mama Badri, my mother comes to me every once in a while

Old man man inqad zahmat-et däd-am,

[I][this much][bother you][I gave]

I'd already troubled you a lot

dige xast-at kard-am,

[any more][tired you] [I did]

and made you tired

xeili mamnun

[very][thank you]

Thank you

man hamin-jā esterāhat mikon-am

[I][this here] [rest] [I do]

I'll wait here

Neighbour -in harfā chi-e dige

[this][words]what is][any more]

Don't say that

-yani mā liāqat-e chand sāat' mehumn dārio nadār-im

[it means][we][deserve][few][hour][guest] [having][we do'n have]?

Are you saying that I don't deserve to have a guest for a couple of hours? 


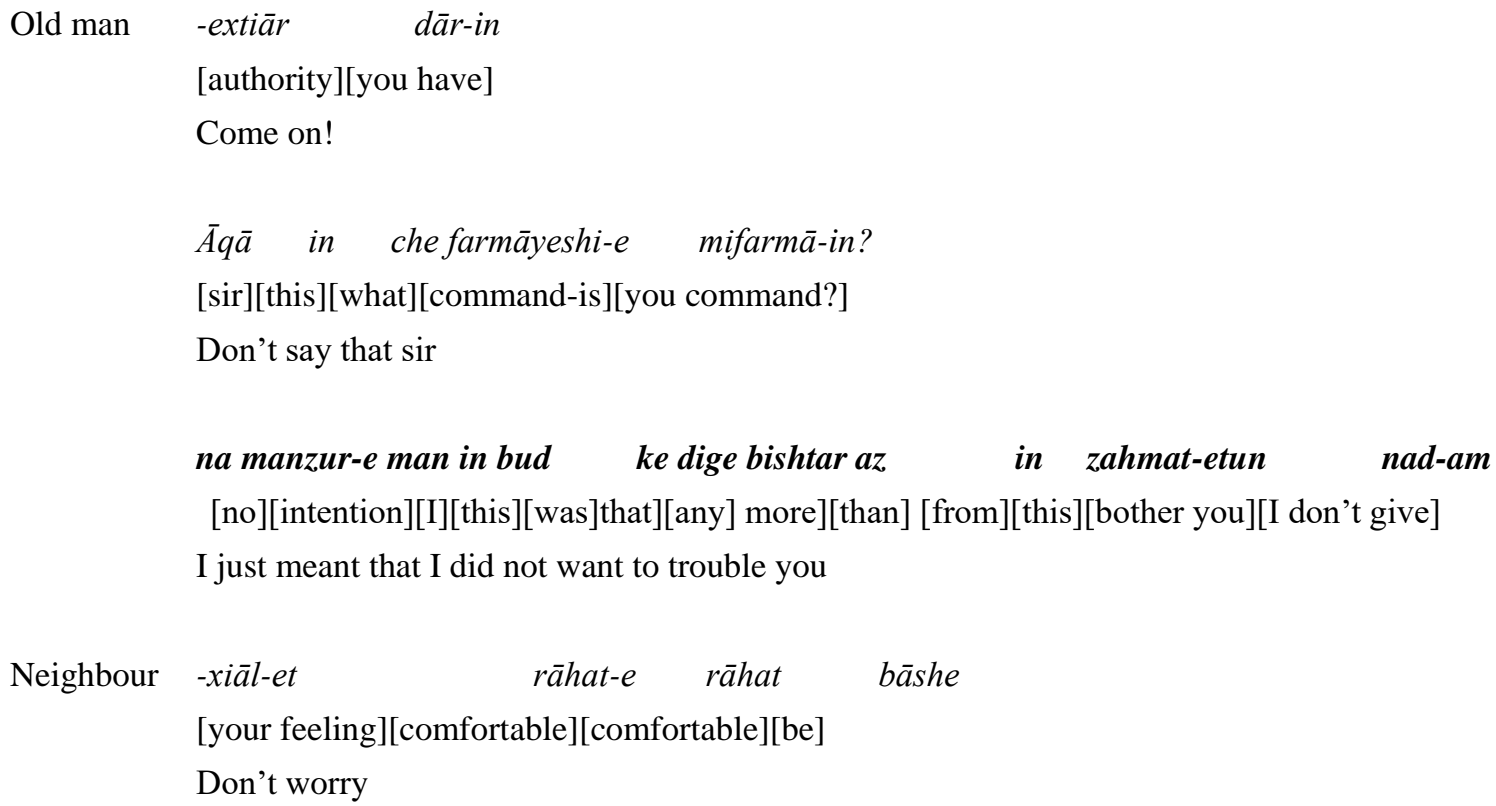

In the previous scenes it was shown that the old man frequently comes from a small city to Tehran (capital of Iran) to visit his nephew. However, they do not open the door for him. In this episode, he is waiting for them to come in the corridor. He has brought a lot of heavy souvenir and he is tired. One of the neighbours genuinely invites him to come to his house. Last month he invited him to his house for the same reason. The old man ostensibly refuses the invitation. However, both the neighbour and the audience know that he is doing ta'arrof. Therefore, the neighbour insists on his invitation. The final act indicates that the invitation were genuine while the refusals were ostensible. In other words, while the overt functions of the refusal are appellative their actual functions are phatic.

\section{Discussion and Conclusion}

Results of the study show that all the ostensible features found in the Persian invitations were included in the list of functions and contexts of Persian ostensible invitations proposed by Eslami (2005. .Result of the interview in Eslami's work show that there is a strong negative attitude toward people who solicit invitations and force themselves on other people (p. 462). Participants in the interview used different phrases in Persian like 'jol', (trash), 'kane' (mosquito), and 'por ru' (shameless) to call these people who exhibit this behaviour. In a similar vein, in all cases, Persian ostensible invitations in the corpus were not solicited and the invitations were ostensibly extended by S voluntarily. Eslami (2005) considers the reason of telephone call as an important criterion for distinguishing genuine and ostensible invitations. In other words, if the invitation is the main reason for the call the invitation can be considered as non-phatic or genuine even if the ostensible features proposed by Isaac \& Clarks (1990) (and repeated by Link \& Kreuz, (2005)) are present in them. 
Allami (2012) concluded that genuine offers in Persian are done for three purposes of offering gift, help, and hospitality. Based on the results, the categorization proved to be applicable to categorize the ostensible offers which were solely used for phatic communication.

Sharifian (2007, p. 249) maintains that "it is a cultural phenomenon that consists of refusing something out of politeness that has been offered to you even though you want it". Analysing the corpus revealed that the characters who refused the invitations, wholeheartedly like to attend the event. However, out of politeness and continuing the conversation (having phatic function) they refused to accept the invitation in the first or second times.

Analysis of the data showed that strategies of IFID namely 'expression of regret' and 'request for forgiveness' were not used in single forms. If they were used in a single form, the addressee as well as the original audience will not understand the reason of the apology. Therefore they were combined with apologies with other strategies such as 'statement of offence' in order to implicate the reason for the apology. The analysis revealed that the only strategy which was used in single form was 'statement of offence'. These offences were 'taking the time of the addressee', 'bad food', 'lack of convenience', 'messiness of the room', etc. However, these apologies were between host and the guest which as Koutlaki (2010) and Saberi (2012) believe are manifestation of ta'ärof rather than real apologies for a real offence. In a similar way, ST audience will understand the ostensible meaning as no offence has been committed by $\mathrm{S}$ and also they can recourse to their knowledge of ta'ārof. About ta'ärof apologies Koutlaki (1997, p. 82) argues that the speaker is ostensibly apologizing for bad food, lack of comfort, waste of the visitors' time: in short, she presents her hospitality as being worse than what the visitors deserve. Results of this study revealed her claim.

Based on the analysis of the data in this study, we propose that in Persian genuine speech acts, overt and actual functions are the same. However, we proved the discrepancy of these function in Persian OSAs as manifestation of ta'ärof. In the following table this discrepancy has been shown:

Table 2. Discrepancy of overt versus Actual functions of speech acts

\begin{tabular}{|c|c|c|l|l|}
\hline $\begin{array}{c}\text { Categories of speech } \\
\text { act of }\end{array}$ & Speech act & Overt function & \multicolumn{2}{|l|}{ Actual function } \\
\cline { 4 - 5 } & & & Genuine & Ostensible \\
\hline Directive & Invitation, Offer & Appellative & Appellative & Phatic \\
\hline Commissive & $\begin{array}{c}\text { Refusal of offer and } \\
\text { invitation }\end{array}$ & Appellative & Appellative & Phatic \\
\hline Expressive & Apology & Expressive & Expressive & Phatic \\
\hline
\end{tabular}

The analysis of the corpus revealed that all the strategies used in the speech acts were included in the frameworks proposed by previous studies for Persian genuine speech acts which by itself confirms the homogeneity of the overt function (structure) of genuine and ostensible speech acts in the corpus. This fact reconfirms the importance of context in distinguishing actual and overt functions of the speech acts in the dialogue. To name a few, 
the role of the movie character, their financial situation, etc. has an effect on the understanding of the ostensible meaning of the speech act. For example, ST audience can infer the ostensible meaning of offer when it is between the landlord and the tenant as this type of offer possesses the feature ' $\mathrm{S}$ is unable to provide what she offers' in English. Role of the characters can be inferred by accessing co-text, polysemiotic signs or from the previous or next scenes.

\section{Acknowledgement}

This work was supported in part by the Universiti Sains Malaysia Bridging Grant Scheme (304/PHUMANITI/6316385).

\section{References}

Afghari, A. (2007). A Sociopragmatic Study of Apology Speech Act Realization Patterns in Persian. Speech Communication, 49, 177-185. Retrieved from https://www.sciencedirect.com/science/article/abs/pii/S0167639307000076

Aliakbari, M., \& Changizi, M. (2012). On the Realization of Refusal Strategies by Persian and Kurdish Speakers. International Journal of Intercultural Relations, 36(5), 659-668. Retrieved from https://www.sciencedirect.com/science/article/abs/pii/S0147176712000491

Allami, H. (2012). A Sociopragmatic Study of the Offer Speech Act in Persian. Research in Applied Linguistics (RALS), 3(1), 110-129. Retrieved from http://rals.scu.ac.ir/pdf_10374_78035447666ba34f963c89b704f3ea99.html

Amouzade, M. (2001). Politeness in Persian. Language Forum, 27, 131-141.

Arcand, R., \& Bourbeau, N. (1995). La communication efficace. De l'intention aux moyens d'expression, Anjou (Québec): CEC.

Ariel, M. (2010). Defining Pragmatics. Cambridge: Cambridge University Press.

Austin, J. (1962). How to Do Things with Words. London: Oxford University Press.

Babai Shishavan, H., \& Sharifian, F. (2013). Refusal Strategies in L1 and L2: A Study of Persian-speaking Learners of English. Multilingua, 32(6), 801-836. Retrieved from https://www.degruyter.com/view/j/multi.2013.32.issue-6/multi-2013-0038/multi-2013-0038.x $\mathrm{ml}$

Babai Shishavan, H. (2016). Refusals of Invitations and Offers in Persian: Genuine or Ostensible?. Journal of Politeness Research Language, Behaviour, Culture, 12(1), 55-93. Retrieved from https://www.degruyter.com/view/j/jplr.2016.12.issue-1/pr-2018-9990/pr-2018-9990.xml

Beeman, W. O. (1986). Language, Status, and Power in Iran. Bloomington: Indiana University Press. 
Bühler, K. (1934). Sprachtheorie. Oxford, England: Fischer.

Bunt, H., \& Black, W. (2000). The ABC of Computational Pragmatics. In: Bunt, H. and W. Black (Eds.), Abduction, Belief and Context in Dialogue: Studies in Computational Pragmatics (pp. 1-46). Amsterdam: John Benjamins.

Capone, A., \& Mey, J. (2015). Interdisciplinary Studies in Pragmatics, Culture and Society, Dordretch: Springer.

Cole, P. (1981). Radical Pragmatics. New York: Academic Press.

Eslami, Z. R. (2005). Invitations in Persian: Ostensible or Genuine?. Intercultural Pragmatics Journal, 2(4), 453-448. Retrieved from https://www.degruyter.com/view/j/iprg.2005.2.issue-4/iprg.2005.2.4.453/iprg.2005.2.4.453.x $\mathrm{ml}$

Ephratt, M. (2008). The Functions of Silence. Journal of pragmatics, 40, 1909-1938.

Fasold, R. (1990). The Socioliguistics of Language. Blackwell: Oxford.

Hebert, L. (2011). The Function of Language. Signo. Retrieved from http://www.signosemio.com/jakobson/functions-of-language.asp

Isaacs, E. A., \& Clark, H. H. (1990). Ostensible Invitations. Language in Society, 19, 493-509. Retrieved from https://web.stanford.edu/ clark/1990s/Isaacs,\%20E.A.\%20_\%20Clark,\%20H.H.\%20_Ostensi ble\%20invitations_\%201990.pdf

Jucker, A. H., \& Taavistsainen. (2008). Speech Acts in the History of English. Amsterdam: John Benjamins Publishing.

Kadmon, N. (2001). Formal Pragmatics: Semantics, Pragmatics, Presupposition, and Focus. Oxford: Blackwell Publishers.

Koutlaki, S. (1997). The Persian System of Politeness and the Persian Folk Concept of Face, with Some Reference to EFL Teaching to Iranian Native Speakers. Unpublished PhD thesis, University of Wales College of Cardiff.

Koutelaki, S. (2002). Offer and Expressions of Thanks as Face-enhancing Acts: Ta'arof in Persian. Journal of Pragmatics, 34, 1733-1756.

Koutlaki, S. (2010). Among the Iranians: A Guide to Iran's Culture and Customs. Boston: Intercultural Press.

Leech, G. (1983). Principles of Pragmatics. London: Longman Group Limited.

Leech, G., \&Thomas, J. (1990). Language, Meaning and Context: Pragmatics. In N.E. Collinge (Ed.), An Encyclopaedia of Language (pp. 173-243). London: Routledge.

Levinson, S. C. (1983). Pragmatics. Cambridge: Cambridge University Press.

Leone, M. (2009). Iranian Ta'ārof and Italian Cerimonie: On the Semiotics of Politeness. In E. 
Tarasti (Ed.), Communication: Understanding/Misunderstanding. Proceedings of the 9th Congress of the International Association for Semiotic Studies Held in Helsinki and Imatra, June 2007 (Vol. 2, pp. 904-914).

Link, K., \& Kreuz, R. (2005). The Comprehension of Ostensible Speech Acts. Journal of Language and Social Psychology, 24, 227-251.

Lyons, J. (1987). Semantics. In J. Lyons (Ed.), New Horizons in linguistics. (Vol. 2, pp. 152-178). London: Penguin,.

Miller, C., Strong, R., Vinson, M., \& Claudia, M. (2014). Ritualized Indirectness in Persian: Ta'ārof and Related Strategies of Interpersonal Management, University of Maryland Center for Advanced Study of Language Technical Report.

Nord. C. (2008). Persuading by addressing: a functional approach to speech-act comparison. Southern African Linguistics and Applied Language Studies, 26(2), 283-293. Retrieved from https://www.tandfonline.com/doi/abs/10.2989/SALALS.2008.26.2.8.572

Nord, C. (2006). Translating as a Purposeful Activity: A Prospective Approach. TEFLIN Journal of Pragmatics, 17(2), 131-143.

Razmjoo, S. A., Barabadi, E., \& Arfa, A. (2013). An investigation into the speech act of compliment response in Persian. International Journal of Applied Linguistics \& English Literature, 2, 44-52.

Recanati, F. (2004). Literal Meaning. Cambridge : Cambridge University Press.

Roberts, C. (2004). Context in Dynamic Interpretation. In Horn, L., \& Ward, G. (Eds.), The Handbook of Pragmatics. Oxford: Blackwell.

Saberi, K. (2012). Routine Politeness Formulae in Persian: A Socio-Lexical Analysis Of Greetings, Leave-taking, Apologizing, Thanking and Requesting. Ph.D. dissertation, University of Canterbury.

Sadock, J. (2007). Speech acts. In L. Horn (Ed.), Handbook of Pragmatics. UK: Blackwell.

Sahragard, R. (2003). A Cultural Script Analysis of a Politeness Feature in Persian. Paper Presented at the 8th Pan-Pacific Association of Applied Linguistics, Japan.

Salmani-Nadoushan, M. A. (2005). A Comparative Sociopragmatic Study of Ostensible Invitations in English and Farsi. Pazhuhesh-e Zabanha-ye Khareji, 20, 119-144.

Salmani Nodoushan, M. A. (2014). Speech Acts or Language Micro- and Macro-game? International Journal of Language Studies, 8(4), 1-28.

Searle, J. R. (1969). Speech Acts: An Essay in the Philosophy of Language. Cambridge: Cambridge University Press.

Searle, J. R. (1979). Expression and Meaning: Studies in the Theory of Speech Acts. Cambridge: Cambridge University Press. 


\section{Mll Macrothink}

Journal for the Study of English Linguistics

ISSN 2329-7034

2019, Vol. 7, No. 1

Shariati, M., \& Chamani, F. (2010). Apology Strategies in Persian. Journal of Pragmatics, 42(6), 1689-99.

Sharifian, F. (2007). L1 Cultural Conceptualisations in L2 Learning: The Case of Persian Speaking Learners of English. In Farzad Sharifian \& Gary Palmer (Eds.), Applied Cultural Linguistics: Implications for Second Language Learning and Intercultural Communication. Amsterdam \& Philadelphia: John Benjamins.

Taleghani-Nikazm, C. (1998). Politeness in Persian Interaction: The Preference Format of Offers in Persian. Cross-roads of Language, Interaction, and Culture, 1, 3-11.

Yaqubi, M. (2012). A cross-cultural Study of Politeness Strategies Applied in Translations of English Requests as Face-threatening Acts into Persian .Modern Journal of language Teaching Methods (MJLTM). 2(2), 31-44. Retrieved from http://mjltm.org/article-1-37en.pdf\#page $=31$

Yaqubi, M, Davoudi Sharifabad, E., \& Abdul Rahman, W. R. E. (2013). Gender-linked Choice Of Politeness Strategies Applied to Translation of Persian Face-threatening Acts into English. International Journal of Applied Linguistics \& English Literature (Special Issue). 1(7), 66-80. Retrieved from http://journals.aiac.org.au/index.php/IJALEL/article/view/799

Yaqubi, M., Abdul Rahman, W., \& Che Omar, Hasuria. (2014). A Prospective Approach to English Subtitling of Persian Phatic Expressions. Translation Studies, 12(45), 83-95. Retrieved from http://journal.translationstudies.ir/index.php/ts/article/view/250

Yaqubi, M., Abdul Rahman, W., \& Che Omar, Hasuria. (2015). Bebaxshid poshtam be shomas" (excuse me, I'm sitting in front of you): Towards Identification of Persian Apologies with Phatic Function. Journal of Applied Linguistics and Language Research, 2(7), 215-221. Retrieved from http://www.jallr.com/index.php/JALLR/article/view/179

Yaqubi, M., Karwan, M. Saeed, \& Khaksari, M. (2016). Conversational Maxim View of Politeness: Focus on Politeness Implicatures raised in Performing Persian Offers and Invitations. Theory and Practice in Language Studies, 6(1), 52-58. Retrieved from https://www.academypublication.com/ojs/index.php/tpls/article/view/tpls06015258

Yaqubi, M. (2018). On Subtitling of Ta'ārof Apologies, Journal of Language and Translation, $8(1)$, 31-42. Retrieved from https://pdfs.semanticscholar.org/b475/e55fe1fac06ff55604003f695c8767e261cf.pdf

Yaqubi, M. (Forthcoming) Subtitling of Ostensible Speech Acts (OSAs): Towards Proposing a Guideline. Spanish Journal of Applied Linguistics.

Yaqubi, M. (Forthcoming) Revisited Interpretation of Ta'ārof: Towards a Model of Analysing Meta- Implicatures of Persian Offers in Iranian Films. Spanish Journal of Applied Linguistics.

Yule, G. (1996). Pragmatics. New York: Oxford University press. 


\section{Copyright Disclaimer}

Copyright for this article is retained by the author(s), with first publication rights granted to the journal.

This is an open-access article distributed under the terms and conditions of the Creative Commons Attribution license (http://creativecommons.org/licenses/by/3.0/). 